\title{
Coloring Power and Changes in Hair Quality from Natural Pigment from Red Paprika
}

\author{
Ju-Sub Kim \\ Department of Cosmetology, Sangji Youngseo College, Wonju-si, Gangwon-do, Korea
}

Corresponding author: Ju-Sub Kim, Department of Cosmetology, Sangji Youngseo College, 84 Sangjidae-gil, Wonju-si, Gangwondo 26339, Korea

Tel.: +82 337300811

Fax: +82337300811

Email: c-miro@hanmail.net

Received April 9, 2018

Revised May 4, 2018

Accepted May 25, 2018

Published September 30, 2018

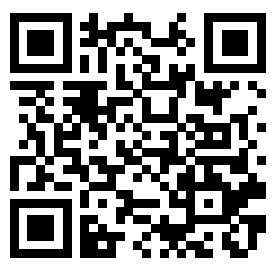

\begin{abstract}
Purpose: This study examines if the natural pigment of red paprika can be used as an ingredient in hair colorants. Methods: In the study, the paprika pigment was applied to hair specimens in varying levels. To investigate coloring performance, $L^{*} a^{*} b^{*}$ value and coloring power were assessed, and to observe hair quality change, hair tensile strength and cuticle images were investigated. Results: As a result, the $L^{*}, a^{*}$, and $b^{*}$ values were found to increase the hair specimen levels moved up in $10 \mathrm{~min}$ and $20 \mathrm{~min}$ of heat treatment. The $\mathrm{dE}$ values were found to increase with a huge gap until hair level 9 in specimens receiving 10-20 min heat treatments. In the 10-20 min heat treated specimens, the $\mathrm{K} / \mathrm{S}$ values, compared to healthy hair, rose slightly with the specimen level increase. The 20 min heat treatment was found to have generally higher coloring power than the 10 min case. Next, it was found that the higher the specimen levels, the lower the tensile strength. Lastly, the cuticle images herein showed that the specimens at higher levels had more detachment than healthy hair. Conclusion: Based on the above findings, it was found that the paprika pigment can be utilized as an ingredient for natural coloring preparation. Further research is recommended to improve the dyeing ability by deepening preand post-treatment studies.
\end{abstract}

Keywords: Paprika, Hair, Natural, Dye power, Change

\section{Introduction}

사람의 아름다움을 표현하는 방법에는 메이크업, 패션, 헤어스 타일 등이 있으며 헤어스타일에 있어서 자신의 아름다움을 표현 하는 방법에는 커트, 퍼머넌트웨이브, 모발염색 등이 있다(Kim, 2010). 모발 염모제는 원료의 차이에 따라 합성 염모제와 천연 염모제로 나뉠 수 있다(Kim et al., 2006). 합성 염모제는 시술 시간을 단축시키고 색상을 잘 표현 할 수 있고 사용이나 보관이 쉬어 오늘날 많이 사용하고 있다. 그러나 합성 염모제는 모발 손 상을 야기한다. 손상의 예로는 인장강도가 떨어지고, 모표피가 열리는 현상을 초래한다. 또한 두피에 염증과 같은 반응을 보일 수 있다. 따라서 두피의 염증 유발이 적은 천연물질을 이용한 발 모 및 두피개선 연구도 이루어지고 있다(Kim, 2014a). 예를 들 어 우엉뿌리 추출물을 이용한 두피와 모발에 미치는 영향에 관한 연구도 진행되었다(Lee et al., 2015). 천연염색은 인류가 자연 의 아름다움을 보고 느끼며 생활하면서 그 아름다운 색채를 간직
하고 싶은 욕망에서 비롯되었다(Lee, 2008). 생활수준 향상으로 건강과 고품격을 중시하는 트랜드 변화에 천연재료를 원료로 하 는 다양한 제품에 대한 수요가 날로 커지고 있다(Kim, 2014b, Kim \& Kwon, 2008). 미용시술에 있어서 염색 시 모발 손상과 두피에 부작용이 생길 수 있어 모발 손상을 적게 하고 두피에 부 작용이 적은 천연재료를 원료로 하는 다양한 천연색소와 천연 염 모제에 대한 관심이 증가하였다(Na, 2007). 천연물질을 이용한 모발의 염색성에 관한 연구 등 자연으로부터 얻을 수 있는 천연 소재를 이용하여 모발의 손상을 완화시키기 위한 연구가 주를 이 루고 있다(Ha \& Ko, 2012). 이러한 천연 염모제에 대한 관심이 커지면서 천연색소를 이용한 염색력 연구가 꾸준히 진행되고 있 다. 천연염색에 사용되는 원료로는 적색계열에는 홍화, 소목, 코 치닐, 꼭두서니 등이 있다(Cho, 2000). 천연염색을 시술하기 위 해서는 천연성분이 첨가된 염모제를 제조하여 사용하거나 천연 염색성분 자체를 모발에 도포하여 염색을 하여야 한다. 본 연구 는 적색을 띄는 파프리카 색소를 이용하여 염색의 염착력을 향상 
시키기 위해 기존에 연구되지 않았던 방법으로 연구를 진행하려 고 한다.

파프리카는 Capsicum annuum L. 이란 학명으로 명명되 어 있고, 고추속(Capsicum), 고추종(annutam)에 속하는 한 해살이 식물로 6 개의 아종이 있다. 파프리카는 sweet pepper, bell pepper, pimento와 같은 말로 통용되며(Lee, 1998), 무 게가 $100 \mathrm{~g}$ 이하의 것을 우리나라에서는 피망이라 부른다(Lee, 2001). 파프리카는 식용으로 재배 되었지만, 최근에야 비타민 A 와 $\mathrm{C}$ 가 풍부하고, $\mathrm{pH}$, 열 및 빛에 안정한 성질을 가지는 알칼리 식품으로 알려져 있다(Jung et al., 2004). 본 연구에는 여러 종 류의 파프리카 중 적색품종인 special 종의 색소를 사용하여 연 구하였다. 선행연구에 따르면 파프리카 색소 함량 중 안토시아 닌 색소는 적색품종 파프리카가 $24.69 \mathrm{mg}$ 로 나타났다(Jeong et al., 2006a). 이러한 파프리카를 이용한 선행연구로는 파프리카 의 색상별 phytochemical 및 항산화능 비교에 대한 연구(Kim et al.. 2011), 파프리카를 이용한 피부 항산화 효과에 관한 연구 (Jeong et al., 2006b) 등이 있다.

본 연구는 다방면에 사용되는 파프리카를 천연염색의 원료로 사용가능한지를 알아보고자 하여 적색 파프리카 분말색소를 액 체로 중탕하여 모발시료에 도포한 후 시료의 염색력을 측정하여 천연색소의 염색효과를 알아보았다. 또한 천연색소 도포로 인한 모발의 성질 변화를 알아보기 위해 인장강도 실험과, 모표피 촬 영을 하여 모질의 변화를 알아보고자 하였다.

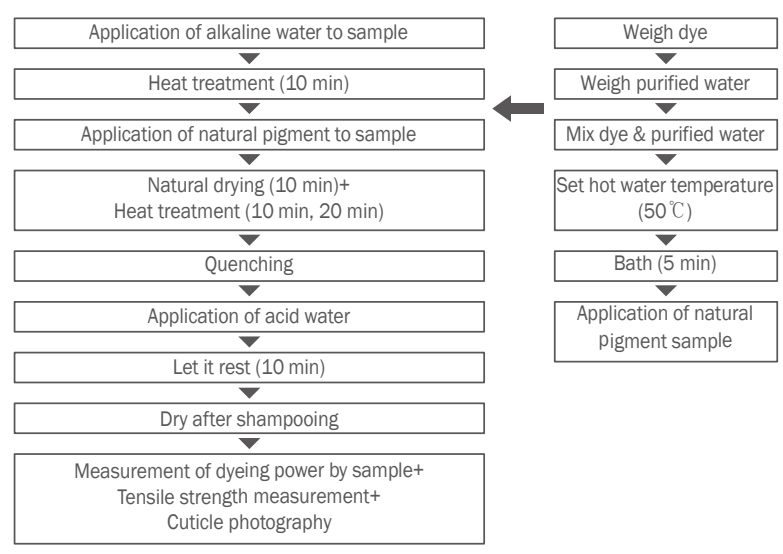

Figure 1. Experimental process.

\section{Methods}

\section{1. 실험재료 및 측정기기 \\ 1) 시료모발}

본 실험에서 사용한 모발 샘플은 2015년 3월부터 서울의 미용 실에서 채취한 건강한 모발의 모근으로부터 $20 \mathrm{~cm}$ 부위에서 25 $\mathrm{cm}$ 이상의 길이로 커트한 모발을 채취하여 사용하였다. 채취한 모발은 화학적 시술을 전혀 하지 않은 버진 헤어로 10 대 후반의 여학생 성모였다. 시료모발을 일정 크기로 실리콘 작업을 하여

\section{Table 1. Sample expression method}

\begin{tabular}{ll}
\hline Experimental group & Contents \\
\hline Paprika 10-virgin hair & Treatment of virgin hair sample with 10-min application of paprika dye \\
Paprika 10-7 level & Treatment of level-7 sample with paprika dye and 10 min heat treatment \\
Paprika 10-9 level & Treatment of level-9 sample with paprika dye and 10 min heat treatment \\
Paprika 10-11 level & Treatment of level-11 sample with paprika dye and 10 min heat treatment \\
Paprika 20-virgin hair & Application of paprika dye to virgin hair sample for 20 min \\
Paprika 20-7 level & Treatment of level-7 sample with paprika dye and 20 min heat treatment \\
Paprika 20-9 level & Treatment of level-9 sample with paprika dye and 20 min heat treatment \\
Paprika 20-11 level & Treatment of level-11 sample with paprika dye and 20 min heat treatment \\
\hline
\end{tabular}

Table 2. Results of samples

\begin{tabular}{l|lll|l|l|}
\hline Heat treatment & Virgin hair & P level & 9 level & 11 level & Paprika dye \\
\hline $10 \mathrm{~min}$ & & & & \\
\hline
\end{tabular}


건강모, 7 레벨 탈색, 9 레벨 탈색, 11 레벨 탈색으로 4가지 레 벨 별로 시료를 제작하였다.

\section{2) 측정기기 및 측정방법}

모표피 촬영은 레벨 별 파프리카 색소 도포 후 자연건조, 열 처리 $10 \mathrm{~min}$, 열처리 $20 \mathrm{~min}$ 시술 후의 모발 형태학적 모표피 의 변화를 관찰하기 위하여 주사전자 현미경(scaning electron microscope, Tescan, Czech)을 사용하였다. 열처리한 실험모의 표면 형태 변화를 분석하기 위해 시료 표면을 1000 배율로 측정 하였다.

인장강도 측정은 각 시료 당 모발 5 가닥을 $15 \mathrm{~cm}$ 로 동일한 길 이에서 인장강도를 측정하여 평균값을 구하였다. 측정기기는 만 능재로시험기(No.4301; Instron, USA)로 인장시험을 실시하였 다. 인장시험의 측정은 섬유단사를 측정하는 한국산업규격 섬유 의 인장강도 및 신도의 시험방법(KS K0323)에 준하여 실시하였 다.

염색력 측정은 각각 시료의 표면색상 변화를 알아보고자 동 일한 조건하에서 색차계(sphere spectrophotometer, SP60; $\mathrm{X}$-Rite, USA)를 이용하여 CIELAB 표색계의 색상 값인 명도 지수 $\mathrm{L}^{*}$ 과 색 좌표 지수인 $\mathrm{a}^{*}$ 와 $\mathrm{b}^{*}$ 값을 구하였다(Kim \& Lee, 1998).

염착량 $(\mathrm{K} / \mathrm{S})$ 은 색차계(JX-777; Color Techno System Corporation, Japan)로 $\lambda_{\max }$ 에서 피염물의 표면 반사율을 측
정하여 Kubelka-Munk 식에 의해 산출했는데 그 식은 $\mathrm{K} /$ $\mathrm{S}=(1-\mathrm{R})^{2} / 2 \mathrm{R}$ 이다. 여기서, $\mathrm{K}$ 는 염색물의 흡광계수(adsorption coefficient)이며, S는 염색물의 산란계수(scattering coefficient)이고, $\mathrm{R}$ 은 표면반사율(reflectance) 이다.

각 측정방법에 따라 측정한 후 측정값의 신뢰성을 위하여 측정 값 중 제일 높은 값과 제일 낮은 값을 제외한 남은 측정값의 평균 값을 구하였다.

\section{2. 실험방법}

본 실험에서 사용한 모발의 굵기는 $0.05 \mathrm{~mm}$ 에서 $0.1 \mathrm{~mm}$ 의 굵기 범위로 측정되었다. 건강모발에 탈색제 제1제(ammonium persulfate, potassium persulfate, sodium metasilicate, magnesium, sodium carboxymethyl cellulose; Suanhj, Korea) $3 \mathrm{mg}$ 와 제2제 $(6 \%$ 의 과산화수소를 주성분으로 water, etidronic acid, phosphoric acid, sodium phosphate dibasic, cetyl alcohol로 구성된 제품; Suanhj) $3 \mathrm{~mL}$ 비율로 혼합하여 도포한 다음 호일로 감싸, 탈색 시술하여 시료레벨 7 레벨, 9 레 벨, 11 레벨의 시료로 제작하였다. 사용한 천연 적색 파프리카 색소는 분말로 추출되어 있어 염색도포가 용이 하도록 중탕으로 만들어 각각의 시료에 도포하여 시료레벨 별로 도포한 후 자연건 조 $10 \mathrm{~min}$, 열처리 $10 \mathrm{~min}$, 열처리 $20 \mathrm{~min}$ 후에 세척하여 측정 하였다. 아래의 Figure 1과 같은 방법으로 실험이 진행되었다.

Table 3. Brightness $L^{*}$ value

\begin{tabular}{|c|c|c|c|c|c|}
\hline Heat treatment & $\begin{array}{c}\text { Bleach hair } \\
11 \text { level }\end{array}$ & $\begin{array}{l}\text { Paprika } 10 \\
\text { virgin hair }\end{array}$ & $\begin{array}{c}\text { Paprika } 10 \\
7 \text { level }\end{array}$ & $\begin{array}{c}\text { Paprika } 10 \\
9 \text { level }\end{array}$ & $\begin{array}{c}\text { Paprika } 10 \\
11 \text { level }\end{array}$ \\
\hline$-10 \min$ & 50.58 & 26.66 & 27.70 & 28.98 & 31.41 \\
\hline Heat treatment & $\begin{array}{c}\text { Bleach hair } \\
11 \text { level }\end{array}$ & $\begin{array}{l}\text { Paprika } 20 \\
\text { Virgin hair }\end{array}$ & $\begin{array}{c}\text { Paprika } 20 \\
7 \text { level }\end{array}$ & $\begin{array}{c}\text { Paprika } 20 \\
9 \text { level }\end{array}$ & $\begin{array}{c}\text { Paprika } 20 \\
11 \text { level }\end{array}$ \\
\hline$-20 \min$ & 50.58 & 25.44 & 25.80 & 25.89 & 26.17 \\
\hline
\end{tabular}

Table 4. a* value

\begin{tabular}{|c|c|c|c|c|c|}
\hline Heat treatment & Bleach hair & $\begin{array}{l}\text { Paprika } 10 \\
\text { virgin hair }\end{array}$ & $\begin{array}{c}\text { Paprika } 10 \\
7 \text { level }\end{array}$ & $\begin{array}{c}\text { Paprika } 10 \\
9 \text { level }\end{array}$ & $\begin{array}{c}\text { Paprika } 10 \\
11 \text { level }\end{array}$ \\
\hline$-10 \min$ & 8.41 & 5.64 & 7.94 & 16.97 & 24.72 \\
\hline Heat treatment & Bleach hair & $\begin{array}{l}\text { Paprika } 20 \\
\text { Virgin hair }\end{array}$ & $\begin{array}{c}\text { Paprika } 20 \\
7 \text { level }\end{array}$ & $\begin{array}{c}\text { Paprika } 20 \\
9 \text { level }\end{array}$ & $\begin{array}{c}\text { Paprika } 20 \\
11 \text { level }\end{array}$ \\
\hline$-20 \mathrm{~min}$ & 8.41 & 8.96 & 10.65 & 16.22 & 28.52 \\
\hline
\end{tabular}

Table 5. $\mathbf{b}^{*}$ value

\begin{tabular}{|c|c|c|c|c|c|}
\hline Heat treatment & Bleach hair & $\begin{array}{l}\text { Paprika } 10 \\
\text { virgin hair }\end{array}$ & $\begin{array}{c}\text { Paprika } 10 \\
7 \text { level }\end{array}$ & $\begin{array}{c}\text { Paprika } 10 \\
9 \text { level }\end{array}$ & $\begin{array}{c}\text { Paprika } 10 \\
11 \text { level }\end{array}$ \\
\hline$-10 \min$ & 51.08 & 3.93 & 4.72 & 12.09 & 14.32 \\
\hline Heat treatment & Bleach hair & $\begin{array}{l}\text { Paprika } 20 \\
\text { Virgin hair }\end{array}$ & $\begin{array}{c}\text { Paprika } 20 \\
7 \text { level }\end{array}$ & $\begin{array}{c}\text { Paprika } 20 \\
9 \text { level }\end{array}$ & $\begin{array}{c}\text { Paprika } 20 \\
11 \text { level }\end{array}$ \\
\hline$-20 \min$ & 51.08 & 2.87 & 4.59 & 9.85 & 10.44 \\
\hline
\end{tabular}




\section{3. 염색 도포방법}

염색력의 차이는 색소 함유량의 차이, 시료의 종류, 자연방치 시간, 열처리시간, 시술자의 숙련도 등에 따라서 색상의 차이가 다를 수 있기 때문에 최대한 오차를 줄이기 위해 시술자는 각 단 계 별로 시술을 하였다. 염색도포방법은 각 제조된 시료에 중탕 한 색소 $10 \mathrm{~g}$ 을 탈색된 각각의 레벨 시료에 도포하였다. 염색력 을 높이는 조건 중 열과, 방치시간의 관계를 알기 위해 각 함량 별로 도포된 염색시료를 자연건조 $10 \mathrm{~min}$ 과 열처리 $10 \mathrm{~min}, 20$ $\min$ 으로 방치시간을 다르게 하여 방치한 후 흐르는 물에 염색소 가 빠지지 않을 때까지 세척하였다. 각 시료 표기 방법은 Table 1 와 같고, 파프리카 색소로 도포한 시료의 사진은 Table 2 와 같 다.

\section{Results and Discussion}

\section{1. 염색력 측정}

파프리카 색소로 도포하여 열처리 $10 \mathrm{~min}, 20 \mathrm{~min}$ 한 결과, 명도 L"값은 Table 3 과 같다. 탈색모는 11 레벨로 탈색을 한 시 료로서 $\mathrm{L}^{*}$ 값이 높게 나타났고, 파프리카 색소로 도포한 후 열처 리 $10 \mathrm{~min}$ 모발시료는 모발의 레벨이 높을수록 큰 차이는 아 니지만 L*값이 증가한 것으로 나타났다. 이는 모발시료의 바탕 레벨이 높을수록 밝기 때문으로 사료된다. 이는 Jang \& Park
(2015)와 Kim \& Park (2014)의 결과와 반대로 나타났다. 그 이 유는 앞선 두 논문의 경우, 같은 레벨에서 염색 시간을 달리한 것 이고 본 연구는 레벨의 차이를 두었기 때문으로 사료된다. 열처 리 $20 \mathrm{~min}$ 한 시료들 역시 시료 별로 보면 시료의 바탕 레벨이 높을수록 L"값이 증가하는 것을 확인할 수 있다. 열처리 $10 \mathrm{~min}$ 한 시료의 건강모와 11 레벨 시료의 $\mathrm{L}^{*}$ 값 차이는 4.75 차이를 보 이고, 열처리 $20 \mathrm{~min}$ 한 시료의 건강모와 11 레벨 시료의 $\mathrm{L}^{*}$ 값 의 차이는 0.73 으로 나타났다. 열처리 $10 \mathrm{~min}$ 과 열처리 $20 \mathrm{~min}$ 의 시료 별로 보면 차이가 있는데 이는 열처리 $20 \mathrm{~min}$ 을 함으로 써 파프리카 색소의 염착이 더 잘 되어서 $\mathrm{L}^{*}$ 값이 오히려 감소한 것으로 사료된다.

레드(red), 그린(green) 축의 열처리 $10 \mathrm{~min}, 20 \mathrm{~min}$ 한 $\mathrm{a}^{*}$ 값의 결과는 Table 4 와 같다. 탈색모는 11 레벨로 탈색을 한 시 료로서 $a^{*}$ 값이 낮게 나타났다. 이는 탈색을 많이 하여 $a^{*}$ 값이 낮 게 나타난 것으로 사료된다. 파프리카 색소로 도포한 후 열처리 $10 \mathrm{~min}$ 한 모발시료는 모발의 레벨이 높을수록 큰 차이로 $\mathrm{a}^{*}$ 값 이 증가하는 것으로 나타났다. 이는 모발 시료의 바탕 레벨이 높 을수록 색상이 잘 표현되기 때문이라 사료된다. 열처리 $20 \mathrm{~min}$ 한 시료들 역시 시료 별로 보면 시료의 바탕 레벨이 높을수록 a* 값이 증가하는 것을 확인할 수 있다. 열처리 $10 \mathrm{~min}$ 한 시료의 건강모와 11 레벨 시료의 $\mathrm{a}^{*}$ 값 차이는 19.08 의 차이를 보이고, 열처리 $20 \mathrm{~min}$ 한 시료의 건강모와 11 레벨 시료의 $\mathrm{a}^{*}$ 값의 차이 는 19.56 으로 나타났다. 열처리 $10 \mathrm{~min}$ 과 열처리 $20 \mathrm{~min}$ 의 시

Table 6. dE value

\begin{tabular}{|c|c|c|c|c|}
\hline Heat treatment & $\begin{array}{l}\text { Paprika } 10 \\
\text { virgin hair }\end{array}$ & $\begin{array}{c}\text { Paprika } 10 \\
7 \text { level }\end{array}$ & $\begin{array}{c}\text { Paprika } 10 \\
9 \text { level }\end{array}$ & $\begin{array}{c}\text { Paprika } 10 \\
11 \text { level }\end{array}$ \\
\hline$-10 \min$ & 2.12 & 22.24 & 30.21 & 19.31 \\
\hline Heat treatment & $\begin{array}{l}\text { Paprika } 20 \\
\text { virgin hair }\end{array}$ & $\begin{array}{c}\text { Paprika } 20 \\
7 \text { level }\end{array}$ & $\begin{array}{c}\text { Paprika } 20 \\
9 \text { level }\end{array}$ & $\begin{array}{c}\text { Paprika } 20 \\
11 \text { level }\end{array}$ \\
\hline$-20 \min$ & 1.38 & 19.16 & 29.49 & 20.45 \\
\hline
\end{tabular}

Table 7. $\mathrm{K} / \mathrm{S}$ value

\begin{tabular}{|c|c|c|c|c|c|}
\hline Heat treatment & Bleach hair & $\begin{array}{l}\text { Paprika } 10 \\
\text { virgin hair }\end{array}$ & $\begin{array}{c}\text { Paprika } 10 \\
7 \text { level }\end{array}$ & $\begin{array}{c}\text { Paprika } 10 \\
9 \text { level }\end{array}$ & $\begin{array}{c}\text { Paprika } 10 \\
11 \text { level }\end{array}$ \\
\hline$-10 \min$ & 2.37 & 2.68 & 2.74 & 3.09 & 3.25 \\
\hline Heat treatment & Bleach hair & $\begin{array}{l}\text { Paprika } 20 \\
\text { virgin hair }\end{array}$ & $\begin{array}{c}\text { Paprika } 20 \\
7 \text { level }\end{array}$ & $\begin{array}{c}\text { Paprika } 20 \\
9 \text { level }\end{array}$ & $\begin{array}{c}\text { Paprika } 20 \\
11 \text { level }\end{array}$ \\
\hline$-20 \min$ & 2.37 & 2.72 & 2.82 & 3.22 & 4.19 \\
\hline
\end{tabular}

Table 8. Tensile strength value

(Unit: $\mathrm{kgf} / \mathrm{mm}^{\mathbf{2}}$ )

\begin{tabular}{|c|c|c|c|c|c|c|}
\hline Heat treatment & Virgin hair & Bleach hair & $\begin{array}{l}\text { Paprika } 10 \\
\text { virgin hair }\end{array}$ & $\begin{array}{c}\text { Paprika } 10 \\
7 \text { level }\end{array}$ & $\begin{array}{c}\text { Paprika } 10 \\
9 \text { level }\end{array}$ & $\begin{array}{c}\text { Paprika } 10 \\
11 \text { level }\end{array}$ \\
\hline$-10 \min$ & 188.3 & 84.6 & 147.6 & 140.9 & 133.1 & 131.5 \\
\hline Heat treatment & Virgin hair & Bleach hair & $\begin{array}{l}\text { Paprika } 20 \\
\text { virgin hair }\end{array}$ & $\begin{array}{c}\text { Paprika } 20 \\
7 \text { level }\end{array}$ & $\begin{array}{c}\text { Paprika } 20 \\
9 \text { level }\end{array}$ & $\begin{array}{c}\text { Paprika } 20 \\
11 \text { level }\end{array}$ \\
\hline$-20 \min$ & 188.3 & 84.6 & 164.9 & 141.9 & 135.5 & 131.0 \\
\hline
\end{tabular}


료 별로 보면 차이가 있는데 이는 열처리 $20 \mathrm{~min}$ 을 함으로써 파 프리카 색소의 염착이 더 잘 되어서 $\mathrm{a}^{*}$ 값이 증가한 것으로 사료 된다.

노랑, 파랑 축의 열처리 $10 \mathrm{~min}$, 열처리 $20 \mathrm{~min}$ 한 $\mathrm{b}^{*}$ 값의 결 과는 Table 5 와 같다. 탈색모는 11 레벨로 탈색을 한 시료로서 $\mathrm{b}^{\star}$ 값이 높게 나타났다. 이는 탈색을 많이 한 결과로 바탕이 밝 은 황색을 띄기 때문으로 사료된다. 파프리카 색소로 도포한 후 열처리 $10 \mathrm{~min}$ 한 모발시료는 모발의 레벨이 높을수록 큰 차이
로 $\mathrm{b}^{*}$ 값이 증가한 것으로 나타났다. 이는 모발 시료의 바탕 레벨 이 높을수록 황색바탕이 잘 표현되기 때문이라 사료된다. 열처리 $20 \mathrm{~min}$ 한 시료들 역시 시료 별로 보면 시료의 바탕레벨이 높을 수록 $\mathrm{b}^{*}$ 값이 증가 한 것을 알 수 있다. 열처리 $10 \mathrm{~min}$ 한 시료의 건강모와 11 레벨 시료의 $\mathrm{b}^{*}$ 값 차이는 10.39 의 차이를 보이고, 열처리 $20 \mathrm{~min}$ 한 시료의 건강모와 11 레벨 시료의 $\mathrm{b}^{*}$ 값의 차이 는 7.57로 나타났다. 열처리 $10 \mathrm{~min}$ 과 열처리 $20 \mathrm{~min}$ 의 시료 별로 보면 차이가 있는데 이는 열처리 $20 \mathrm{~min}$ 을 함으로써 파프

\section{Table 9. Results on surface of hair}

\begin{tabular}{|c|c|c|c|}
\hline Sample & Cuticle & Sample & Cuticle \\
\hline Bleach hair & & Bleach hair & \\
\hline $\begin{array}{l}\text { Paprika } 10 \\
\text { virgin hair }\end{array}$ & & $\begin{array}{l}\text { Paprika } 20 \\
\text { virgin hair }\end{array}$ & \\
\hline $\begin{array}{l}\text { Paprika } 10 \\
7 \text { level }\end{array}$ & & $\begin{array}{l}\text { Paprika } 20 \\
7 \text { level }\end{array}$ & \\
\hline $\begin{array}{l}\text { Paprika } 10 \\
9 \text { level }\end{array}$ & & $\begin{array}{l}\text { Paprika } 20 \\
9 \text { level }\end{array}$ & \\
\hline $\begin{array}{l}\text { Paprika } 10 \\
11 \text { level }\end{array}$ & & $\begin{array}{l}\text { Paprika } 20 \\
11 \text { level }\end{array}$ & \\
\hline
\end{tabular}


리카 색소의 염착이 더 잘 되어서 $\mathrm{b}^{*}$ 값이 감소한 것으로 나타났 다. 이는 파프리카 색소가 적색이어서 열처리를 오래 할수록 적 색의 염착력이 높아서 나타난 결과로 사료된다.

색차인 $\mathrm{dE}$ 값의 결과는 Table 6 과 같다. 건강모를 기준으로 색차 값의 차이를 알아보았다. 파프리카 색소로 도포한 후 열처 리 $10 \mathrm{~min}$ 한 모발시료는 모발의 레벨이 9 레벨까지는 큰 차이 로 $\mathrm{dE}$ 값이 증가하고 11 레벨에서는 감소한 것으로 나타났다. 이는 대조군인 건강모의 색상의 흑갈색이고 파프리카색소를 건 강모에 도포한 후 $10 \mathrm{~min}$ 열처리 한 모발과는 거의 차이가 미미 한 결과가 나타났고, 탈색을 한 모발에는 큰 차이의 색차를 보였 다. 11 레벨에서 감소한 이유는 11 레벨까지 탈색을 많이 하여 황색의 바탕에 적색을 띄는 효과가 오히려 9 레벨보다 감소한 것 으로 사료된다. 이는 각 색깔 별로 색이 가장 잘 표현되는 밝기의 레벨이 있는데 파프리카 적색은 9 레벨의 시료에서 가장 표현이 잘 된다고 할 수 있다. 열처리 $20 \mathrm{~min}$ 한 시료들 역시 시료 별로 보면 시료의 바탕레벨이 높을수록 $\mathrm{dE}$ 값이 증가하는 것을 확인 할 수 있으나, 열처리 $10 \mathrm{~min}$ 한 결과와 마찬가지로 11 레벨이 9 레벨보다 건강모와 대조하였을 때 $\mathrm{dE}$ 값이 낮아졌다. 이는 열 처리 $10 \mathrm{~min}$ 한 결과와 동일하다고 사료된다. 열처리 $10 \mathrm{~min}$ 과 열처리 $20 \mathrm{~min}$ 의 $\mathrm{dE}$ 값의 차이는 시료별로 보면 거의 비슷한 값 을 보이고 있다. 이는 파프리카 흑갈색의 건강모와 파프리카 적 색소와의 색차가 열처리 $10 \mathrm{~min}, 20 \mathrm{~min}$ 에서는 크게 차이가 없 는 것을 확인할 수 있다.

염착량 $(\mathrm{K} / \mathrm{S})$ 의 결과는 Table 7 과 같다. $\mathrm{K} / \mathrm{S}$ 값은 열처리 10 $\min$ 한 시료를 건강모와 비교 하면 시료의 레벨이 높을수록 소 폭 증가한 것을 알 수 있다. 열처리 $20 \mathrm{~min}$ 한 시료 역시 건강모 와 비교하면 소폭 증가한 것을 확인할 수 있다. 열처리 $10 \mathrm{~min}$ 한 시료 중 건강모와 파프리카 11 레벨의 K/S 값 차이를 보면 0.88 을 보이고, 열처리 $20 \mathrm{~min}$ 한 시료 중 건강모와 파프리카 11 레벨의 $\mathrm{K} / \mathrm{S}$ 값 차이를 보면 1.82 를 보였다. 각 레벨 별 시료 를 비교하면 열처리 $10 \mathrm{~min}$ 한 것보다 열처리 $20 \mathrm{~min}$ 한 것의 염착력이 미비하나마 소폭 증가한 것을 확인할 수 있다. 이는 열 처리를 $10 \mathrm{~min}$ 더 한 결과라고 사료된다. 이 결과는 검정콩 종 피를 이용한 모발의 천연염색 연구결과인 염색온도가 증가할수 록 $\mathrm{K} / \mathrm{S}$ 값도 크게 증가하고 또한 염색시간이 증가할수록 $\mathrm{K} / \mathrm{S}$ 값도 증가한다(Lee \& Park, 2012)는 연구결과와 같다.

\section{2. 인장강도 측정}

인장강도 측정결과는 Table 8 과 같다. 열처리 $10 \mathrm{~min}$ 한 시료 를 건강모와 비교하면 시료의 레벨이 높을수록 인장강도는 감소 하는 것으로 나타났다. 건강모보다 낮게 나타나는 이유는 시료의 레벨이 높을수록 탈색을 많이 한 결과로 사료된다. 탈색을 많이 하여 모발의 결합력이 떨어진 결과로 사료된다. 이유는 모발의 손상을 가장 많이 초래하는 탈색제에 의해 모표피 내의 세포막
복합체 유실과 함께 모피질 간충물질의 유실로 인장강도가 저하 된 것이다(Kang \& Choe, 2007). 또한 모발은 화학적으로 단백 질 중의 시스틴(cysteine)의 함량이 감소하여 물리적으로 인장 강도가 감소된 것이다(Oh \& Choe, 2012). 그러나 탈색모와 비 교 했을 시에는 높은 것으로 나타났다. 이는 파프리카 색소가 모 발에 염착이 되어 인장강도가 증가한 것으로 보인다. 열처리 20 $\mathrm{min}$ 한 시료를 건강모와 비교하면 열처리 $10 \mathrm{~min}$ 한 결과와 마 찬가지로 건강모와 비교 시 시료의 레벨이 높을수록 인장강도 가 감소하는 것으로 나타났고, 탈색모와 비교 시에는 높은 것으 로 나타났다. 그 이유는 열처리 $10 \mathrm{~min}$ 한 결과와 동일한 이유 라고 사료된다. 열처리 $10 \mathrm{~min}$ 한 것과 열처리 $20 \mathrm{~min}$ 한 것의 인장강도 비교 시에는 레벨 별로 거의 비슷하나 열처리 $20 \mathrm{~min}$ 한 건강모, 7 레벨, 9 레벨은 열처리 $10 \mathrm{~min}$ 한 것보다 소폭 증 가한 것을 알 수 있다. 이는 열처리를 $10 \mathrm{~min}$ 더 한 결과로 염 착이 좀 더 잘 된 것으로 보인다. 11 레벨에서는 거의 비슷한 결 과가 나타났다.

\section{3. 모표피 촬영}

모표피 촬영결과는 Table 9 와 같다. 열처리 $10 \mathrm{~min}$ 한 시료 들의 모표피 촬영결과 건강모와 레벨 별 시료 비교 시 건강모는 모표피의 문리가 뚜렷하게 연결되어 보인다. 그러나 9 레벨의 시료의 모표피는 최외 모표피가 조금 박리가 되어 문리의 연결 이 안 되는 부분이 보인다. 탈색 헤어의 큐티클의 문리가 심하게 용해된다(Min et al., 2011)라는 결과와 동일할 결과로 탈색으 로 인한 결과로 보인다. 11 레벨 시료의 모표피는 이미 탈색을 2 번 이상 한 시료로 큐티클이 거의 다 박리가 되어 보이지 않아, 대조군인 탈색모와 별 차이가 없는 것으로 보인다. 열처리 20 $\min$ 한 모발 역시 건강모 보다는 탈색을 많이 하여 레벨을 높게 한 시료 일수록 모표피의 문리가 연결이 안되고 모표피가 박리 되는 것을 볼 수 있다. 이 또한 탈색에 의한 모표피의 손상으로 인한 것으로 사료된다. 열처리 $10 \mathrm{~min}$ 한 것과 열처리 $20 \mathrm{~min}$ 한 것의 모표피를 비교하면 7 레벨 9 레벨의 모표피에서는 열처 리 $20 \mathrm{~min}$ 의 모표피가 좀 더 박리가 많이 되어 문리의 연결이 안되는 것을 알 수 있다. 이는 열처리를 $10 \mathrm{~min}$ 더 한 결과로 볼 수 있다.

\section{Conclusion}

천연 적색 파프리카 색소가 모발염색의 원료로 사용가능 여부 를 알아보기 위해 파프리카 색소를 중탕하여 각각의 모발 레벨 별로 도포하였다. 도포한 시료를 자연건조 $10 \mathrm{~min}$ 하고, 열처 리 $10 \mathrm{~min}$, 열처리 $20 \mathrm{~min}$ 을 한 후 세척하였다. 세척한 시료의 염색력을 알아보기 위해 $\mathrm{L}^{*} \mathrm{a}^{*} \mathrm{~b}^{*}$ 값과 염착력을 측정하였다. 또한 
모질의 변화를 알아보기 위해 인장강도를 측정하고, 모발의 손 상 정도를 알아보기 위해 모표피 촬영을 하였다.

첫째, 염색력 측정결과, $\mathrm{L}^{*}$ 값은 파프리카 색소로 도포한 후 열처리 $10 \mathrm{~min}$, 열처리 $20 \mathrm{~min}$ 한 모발시료는 모발의 레벨이 높을수록 큰 차이는 아니지만 $\mathrm{L}^{*}$ 값이 증가한 것으로 나타났다. $\mathrm{a}^{*}$ 값은 열처리 $10 \mathrm{~min}$ 과 열처리 $20 \mathrm{~min}$ 모발시료는 모발의 레 벨이 높을수록 큰 차이로 $\mathrm{a}^{\star}$ 값이 증가한 것으로 나타났다. 이는 모발시료의 바탕 레벨이 높을수록 색상이 잘 표현되기 때문이라 사료된다. $b^{*}$ 값은 열처리 $10 \mathrm{~min}$ 과 열처리 $20 \mathrm{~min}$ 모발시료는 모발의 레벨이 높을수록 큰 차이로 $\mathrm{b}^{*}$ 값이 증가한 것으로 나타 났다. 이는 모발시료의 바탕 레벨이 높을수록 황색바탕이 잘 표 현되기 때문이라 사료된다. 열처리 $10 \mathrm{~min}$ 과 열처리 $20 \mathrm{~min}$ 의 시료 별로 보면 차이가 있는데 이는 열처리 $20 \mathrm{~min}$ 을 함으로써 파프리카 색소의 염착이 더 잘 되어서 $\mathrm{b}^{*}$ 값이 감소한 것을 알 수 있다. 색차인 $\mathrm{dE}$ 값의 결과는 열처리 $10 \mathrm{~min}$ 과 열처리 $20 \mathrm{~min}$ 모발시료는 모발의 레벨이 9 레벨까지는 큰 차이로 $\mathrm{dE}$ 값이 증 가하고 11 레벨에서는 감소한 것으로 나타났다. 11 레벨에서 감소한 이유는 11 레벨까지 탈색을 많이 하여 황색의 바탕에 적 색을 띄는 효과가 오히려 9 레벨보다 감소한 것으로 사료된다. 이는 열처리 $10 \mathrm{~min}$ 의 결과와 동일하다고 사료된다. $\mathrm{K} / \mathrm{S}$ 값은 열처리 $10 \mathrm{~min}$ 과 열처리 $20 \mathrm{~min}$ 한 시료를 건강모와 비교하면 시료의 레벨이 높을수록 소폭 증가한 것을 알 수 있다.

둘째, 인장강도 측정결과, 열처리 $10 \mathrm{~min}$ 과, 열처리 $20 \mathrm{~min}$ 시료를 건강모와 비교하면 시료의 레벨이 높을수록 인장강도는 감소하는 것으로 나타났다. 건강모보다 낮게 나타나는 이유는 시료의 레벨이 높을수록 탈색을 많이 한 결과로 사료된다. 탈색 을 많이 하여 모발의 결합력이 떨어진 결과로 사료된다.

셋째, 모표피 촬영결과, 열처리 $10 \mathrm{~min}$, 열처리 $20 \mathrm{~min}$ 시료 들의 모표피 촬영결과 건강모와 레벨 별 시료 비교 시 건강모는 모표피의 문리가 뚜렷하게 연결되어 보인다. 그러나 9 레벨의 시료의 모표피는 최외모표피가 조금 박리가 되어 문리의 연결이 안 되는 부분이 보인다. 이는 탈색으로 인한 결과로 보인다.

천연 적색 파프리카 색소로 염색력과 모질의 변화를 연구 한 결론은 천연 염색의 원료로 충분히 사용 가능하다는 것을 알 수 있었다. 열처리 $10 \mathrm{~min}$ 보다는 열처리 $20 \mathrm{~min}$ 일 때 전체적으 로 염색력이 우수함을 알 수 있었고, 인장강도는 탈색모발보다 는 증가한 것으로 나타나 모질의 개선에도 도움을 주는 것으로 나타났다. 다만 모표피는 레벨을 맞추기 위해 탈색을 한 이유로 손상이 있었으나 파프리카 색소에 의한 손상을 아님을 알 수 있 었다. 차후 염색력을 높이기 위한 전처리, 후처리 연구를 심도 있게 하여 염색력을 더욱 높이는데 연구가 필요하다고 생각한 다.

\section{References}

Cho KL. Natural dyestuffs and dyeing. Hyungseol Publishing, Seoul, p160, 2000.

$\mathrm{Ha} \mathrm{JH}$, Ko KS. Degree of hair damage and morphological change of permanent wave using Chamaecyparis obtusa oil. Journal of The Korean Society of Cosmetology, 18: 1264-1269, 2012.

Jang AS, Park $\mathrm{CH}$. A study on the hair dyeing and colorfastness using extracts of Mulberry. Asian Journal of Beauty and Cosmetology, 13: 237-242, 2015.

Jeong $\mathrm{CH}$, Ko WH, Cho JR, Ahn CG, Shim KH. Chemical components of Korean paprika according to cultivars. Korean Journal of Food Preservation, 13: 43-48, 2006 a.

Jeong $\mathrm{CH}$, Ko WH, Cho JR, Ahn CG, Shim KH. Antioxidative and nitrite scavenging activities of Korean paprika according to cultivars. Journal of Agriculture \& Life Science, 40: 27-34, 2006b.

Jung JY, Choi MH, Hwang JH, Chung JH. Quality characteristics of jeung-pyun prepared with paprika juice. Journal of the Korean Society of Food Science and Nutrition, 33: 869874, 2004.

Kang KY, Choe TB. Determination of hair damage by bleach agent and the effect of hair care treatment. Journal of The Korean Society of Cosmetology, 13: 955-963, 2007.

Kim KJ, Lee JM. Chemistry of dyeing. Hyungseul Publishing, Seoul, p102, 1997.

Kim KS. Research trends relevant with hair growth promotion and scalp condition improvement by applying natural extracts. Asian Journal of Beauty and Cosmetology, 12: 17-24, $2014 a$.

Kim JS. Dyeing power of coating permanent to utilize a kaoliang pigment. Asian Journal of Beauty and Cosmetology, 12: 127-132, 2014b.

Kim JS, Lim DJ, Shin HC. Hair coloring mate. Leegline Publishing, Seoul, p62, 2006.

Kim JY, Park $\mathrm{CH}$. Hair dyeing properties using extracts of Aronia melancocarpa. Asian Journal of Beauty and Cosmetology, 12: 663-668, 2014.

Kim HH, Kwon TJ. Effect of protease on the morphological properties and dyeability of human hair. Textile Coloration and Finishing, 20: 59-65, 2008.

Kim JS, Ahn J, Ha TY, Rhee HC, Kim S. Comparison of phytochemical and antioxidant activities in different 
color stages and varieties of paprika harvested in Korea. Korean Journal of Food Science and Technology, 43: 564-569, 2011.

Lee MS, Joung JS, Park DY. The effects of Arctium lappa L. root extracts on the scalp and hair. Asian Journal of Beauty and Cosmetology, 13: 43-48, 2015.

Lee JR, Park $\mathrm{CH}$. Natural hair dyeing using a black soybean seed coat. Journal of Investigative Cosmetology, 8: 127134, 2012.

Lee JW. Techniques of cultivation and quality management for sweet pepper. Protected Horticulture and Plant Factory, 11: 17-28, 1998.

Lee JW. Present condition of paprika cultivation and its prospects for export. Protected Horticulture and Plant
Factory, 14: 36-41, 2001.

Lee HY. A study on the subjective symptom in eye ball and human body of hair dyeing. The Journal of the Korean Society of Make-up Design, 4: 109-116, 2008.

Min MJ, Na MS, Ryu EM, Cha WS. Gray mullet extract on physical damage of colored and bleached hair. Asian Journal of Beauty and Cosmetology, 9: 133-141, 2011.

$\mathrm{Na}$ YY. The dyeing quality for hair by use of the outer coats of onions. Journal of Korea Society of Color Studies, 21: 4350, 2007.

Oh MS, Choe TB. Determination of hair damage index using methylene blue staining method. Journal of The Korean Society of Cosmetology, 18: 531-537, 2012. 


\section{국문초록}

\section{천연 적색 파프리카 색소에 의한 모발 염색력과 모질의 변화}

김주섭

상지영서대학교 뷰티케어과, 강원도 원주시, 한국

목적: 본 연구는 천연 적색 파프리카 색소가 모발염색 원료로 사용 가능한지를 알아보기 위한 것이다. 방법: 파프리카 색소를 모발 시료에 레벨 별로 도포한 후, 염색력을 알아보기 위해 $\mathrm{L}^{*} \mathrm{a}^{*} \mathrm{~b}^{*}$ 값과 염착력을 측정하였다. 모발의 성질 변화를 알아보기 위해 인장강 도와 큐티클 촬영을 하였다. 결과: 첫째, $\mathrm{L}^{*}$ 값, $\mathrm{a}^{*}$ 값, $\mathrm{b}^{*}$ 값은 열처리 $10 \mathrm{~min}, 20 \mathrm{~min}$ 일 때 모발시료의 레벨이 증가할수록 증가하였 다. 열처리 $10 \mathrm{~min}$ 과 열처리 $20 \mathrm{~min}$ 모발시료는 9 레벨까지 큰 차이로 $\mathrm{dE}$ 값이 증가하였으나 11 레벨에서는 감소한 것으로 나타났 다. $\mathrm{K} / \mathrm{S}$ 값은 열처리 $10 \mathrm{~min}, 20 \mathrm{~min}$ 모발시료를 건강모와 비교한 결과, 시료의 레벨이 높을수록 소폭 증가하였다. 열처리 $10 \mathrm{~min}$ 보다는 열처리 $20 \mathrm{~min}$ 일 때 전체적으로 염색력이 우수하였다. 둘째, 인장강도 측정결과, 건강모와 비교하면 시료의 레벨이 높을수 록 인장강도는 감소하였다. 셋째, 모표피 촬영 결과, 건강모보다는 레벨이 높은 모발의 모표피가 박리가 많이 되었다. 결론: 천연 염색의 원료로 파프리카 색소가 충분히 사용 가능함을 확인할 수 있었다. 차후 염색력을 높이기 위한 전처리, 후처리 연구를 심도 있게 하여 염색력을 더욱 높이는데 연구가 필요하다고 사료된다.

핵심어: 파프리카, 모발, 자연, 염색력, 변화

\section{참고문헌}

강갑연, 최태부. 탈색제에 의한 모발 손상 측정 및 모발 보호제 처리 효과. 한국미용학회지, 13: 955-963, 2007. 김경숙. 천연추출물을 이용한 발모 및 두피 개선에 관한 연구 동향. 아시안뷰티화장품학술지, $12: 17-24,2014$. 김공주, 이정문. 염색화학. 형설출판사, 서울, $\mathrm{p} 102,1997$.

김지선, 안지윤, 하태열, 이한철, 김선아. 국내산 파프리카의 색상별 phtochemical 및 항산화능 비교. 한국식품과학회지, 43: 564-569, 2011.

김주섭. 고량색소를 첨가한 코팅퍼머제의 염색력. 아시안뷰티화장품학술지, 12: 127-132, 2014. 김주섭, 임대진, 신홍철. 헤어컬러링 메이트. 리그라인, 서울, $\mathrm{p} 62,2006$.

김주영, 박철호. 아로니아(Aronia melancocarpa) 추출물을 이용한 모발의 염색 특성. 아시안뷰티화장품학술지, 12 : 663-668, 2014.

김홍희, 권태종. 프로테아제 처리가 모발의 염색성 및 형태적 특성에 미치는 영향. 한국염색가공학회지, 20: 59-65, 2008.

나윤영. 양파 외피를 이용한 모발의 염색성. 한국색체학회논문집, 21: 43-50, 2007.

민명자, 나명순, 류은미, 차월석. 숭어추출물이 염색과 탈색 모발의 물리적 손상에 미치는 영향. 아시안뷰티화장품학술지, 9: 133-141, 2011.

이미선, 정지선, 박도영. 우엉뿌리 추출물이 두피와 모발에 미치는 영향. 아시안뷰티화장품학술지, 13: 43-48, 2015. 이정례, 박철호. 검정콩 종피를 이용한 모발의 천연염색. 대한미용학회지, 8: 127-134, 2012.

이재욱. 파프리카(단고추) 재배기술 및 품질관리 요령. 시설원예·식물공장, 11: 17-28, 1998. 이재욱. 착색단고추(파프리카) 재배현황 및 수출전망. 시설원예·식물공장, 14: 36-41, 2001. 이혜영. 모발 염색시 안구와 인체에 미치는 자각증상에 관한 연구. 한국메이크업디자인학회지, 4: 109-116, 2008. 오명숙, 최태부. Methylene Blue 염색법을 이용한 모발손상지수의 결정. 한국미용학회지, 18: 531-537, 2012. 장애선, 박철호. 오디(Mulberry) 추출물의 모발 염색 및 견뢰도 연구. 아시안뷰티화장품학술지, 13: 237-242, 2015. 
정창호, 고웅혁, 조정래, 안철근, 심기환. 한국산 파프리카의 품종별 화학성분. 한국식품저장유통학회지, $13: 43-48$, 2006a.

정창호, 고웅혁, 조정래, 안철근, 심기환. 한국산 파프리카의 품종별 항산화 및 아질산염 소거 활성. 농업생명과학연구, 40: 27-34, 2006b.

정진영, 최민희, 황정현, 정해정. 파프리카즙을 첨가한 증편의 품질 특성. 한국식품영양과학회지, 33: 869-874, 2004. 조경래. 천연염료와 염색. 형설출판사, 서울, $\mathrm{p} 160,2000$.

하진희, 고경숙. 편백정유를 이용한 퍼머넌트 웨이브의 모발 손상도 및 형태학적 변화. 한국미용학회지, 18: 1264-1269, 2012. 


\section{中文摘要}

\section{天然红灯笼辣椒色素对头发染色能力和头发质量的影响}

金周焂

尚志岭西大学美容学科, 江原道原州市，韩国

目的：探讨天然红灯笼辣椒色素是否可用作染发的原料。方法：将红灯笼辣椒色素以不同的水平施用于毛发样 本。为了研究着色性能, 评估 $L^{*} a^{*} b^{*}$ 值和着色力, 并观察头发质量变化, 研究头发拉伸强度和角质层图像。结 果：首先， L“值， $a^{*}$ 值和 $b^{*}$ 值随着热处理 $10 \mathrm{~min}$ 和 $20 \mathrm{~min}$ 时，毛发水平的增加而增加。热处理 $10 \mathrm{~min}$ 和热处理 $20 \mathrm{~min}$ 的头发样品的 $\mathrm{dE}$ 值增加至第9水平, 但在第11水平下降。热处理 $10 \mathrm{~min}$ 和 $20 \mathrm{~min}$ 的样品与健康头发进 行比较, $\mathrm{K} / \mathrm{S}$ 值随着样品的水平略微增加。热处理 $20 \mathrm{~min}$ 的染色能力优于10 min热处理。其次, 拉伸强度随着 样品水平的增加而降低。第三, 毛角质层图像显示, 较高水平的样本比健康头发具有更多的脱离。结论: 作为 天然染色的原料，证实红灯笼辣椒颜料可充分使用。建议进一步深化前处理和后处理研究来提高染色能力。

关键词: 红灯笼辣椒, 头发, 自然, 染色能力, 变化 
